\title{
FDI Effects on National Competitiveness: A Cluster Approach
}

\author{
Philippe Gugler • Serge Brunner
}

Published online: 13 April 2007

(C) International Atlantic Economic Society 2007

\begin{abstract}
Despite the close relationship between the activities of multinational enterprises (MNEs) and the competitiveness of host countries, few studies have linked these two subjects from a global perspective. Combining Porter's approach and the work accomplished by international business economists provides a powerful analytical tool with which to review the recent empirical and theoretical literature on the effects of foreign direct investment (FDI) on national competitiveness. The contention is that FDI can indeed be a source of competitiveness but that previous studies have neglected the role of location, in particular the role of clustering on the absorptive capacity of the host State. The aim of this paper is to provide a comprehensive conceptual framework for assessing the effects of FDI on competitiveness to guide policy-makers as well as further research.
\end{abstract}

Keywords FDI $\cdot \mathrm{MNE} \cdot$ Competitiveness $\cdot$ Cluster $\cdot$ Investment policy

JEL $\mathrm{L} 50 \cdot \mathrm{O} 10 \cdot \mathrm{R} 10$

\section{Introduction}

Despite the close relationship between the activities of multinational enterprises (MNEs) and the competitiveness of recipient countries, few studies have linked these two subjects from a global perspective. This is surprising, given that two major schools have provided important contributions on both issues: namely, the

This study is part of the research project entitled, "Multilateral Rules on Trade and Investment," supported by the NCCR project "International Trade Regulation: From Fragmentation to Coherence," World Trade Institute (WTI), Berne.

\footnotetext{
P. Gugler $\cdot$ S. Brunner $(\bowtie)$

Department of Economics, Faculty of Economics and Social Sciences, University of Fribourg,

Fribourg, Switzerland

e-mail: serge.brunner@unifr.ch

를 Springer
} 
"international business scholar community" and the "Porter school" (Porter 1990, 1998; Dunning 1993). Since the 1990s, several scholars of international business have analysed the relevance of the Porter model in the light of the theory of international production. The need to adapt both schools has been addressed and some studies have been conducted in this regard (Birkinshaw and Sölvell 2000). There is, however, still room for a more in-depth analysis of the impact of foreign direct investment (FDI) on the competitiveness of host countries.

In our opinion, there is a need to review the existing literature on the effects of FDI on national competitiveness, since the cluster dimension has previously been neglected. The aim of this paper is to provide an overview of what we actually know about the impact of FDI on national competitiveness. The theoretical framework developed may subsequently be used to guide policy-makers as well as to inform further research. We will base our paper on the Porter approach, and by reference to the work accomplished by international business economists, we will connect the two approaches.

This paper is structured as follows. To provide a comprehensive assessment, we first outline a theoretical framework combining elements from Porter's theory and from the school of international business. Second, we review the existing theoretical and empirical literature on technology transfer and the upgrading of human capital on the basis of this framework. In the third section we refocus our lens from the usual national dimension to the cluster dimension. We argue that the cluster dimension is more significant in analysing the effects of FDI on a micro level as both MNE activity and absorptive capacity, are better captured on the cluster level. Finally, the policy implications of the findings are elaborated.

\section{The Diamond of National Competitiveness and MNEs}

Because the term competitiveness means different things to different people, it is important at the outset that we have a working definition. Like Porter, we assume that "the only meaningful concept of competitiveness at the national level is productivity" (Porter 1998, p. 160). Why are firms in a particular nation more productive in a certain industry? According to Porter (1990), the answer lies in four broad attributes of a nation that shape the environment in which local firms compete.

\section{Porter's Diamond}

Whether a nation achieves international success in a particular industry is determined by four broad attributes of that nation which promote or impede the creation of competitive advantage (Porter 1990). These are as follows:

(1) Factor conditions: the nation's position in factors of production such as skilled labour, infrastructure, physical resources and technologies, necessary to successfully compete in a given industry;

(2) Firm strategy, structure and rivalry: the conditions in the nation governing how companies are created, organized and managed as well as the nature of domestic rivalry; 
(3) Related and supporting industries: the presence or absence in the nation of supplier industries and related industries and institutions (research, education) that are internationally competitive; and

(4) Demand conditions: the nature (from a qualitative and/or quantitative point of view) of home demand for the industry's products or services.

These determinants, individually and as a system, create the context in which a nation's firms are born and compete (Porter 1990, p. 71). The diamond is a mutually reinforcing system which is also influenced by the government and by chance events.

National economies are neither identical nor static. Porter distinguishes three major stages of competitive development reflecting the specific sources of advantage of a nation's firms in international competition and the nature and extent of internationally successful industries and clusters: factor-driven, investment-driven, and innovation-driven (Porter 1990, p. 545). This categorisation does not provide an adequate description of the situation of countries in the real world and is not intended to do so. Indeed, Porter (1990, p. 545) notes that "no nation will fit a stage exactly." Nevertheless, the following categorisation offers a powerful analytical tool for highlighting the elements that are important for a particular nation's industry.

In factor-driven economies, virtually all internationally successful industries draw their advantage almost entirely from favourable factor conditions, such as plentiful natural resources, favourable growing conditions for certain crops, or an abundant and inexpensive pool of semi-skilled labour (Porter 1990, pp. 546-547). Firms compete primarily on the basis of price in industries that require either little product and process technology or technology that is inexpensive and widely available. In the investment-driven stage, national competitive advantage is based on the willingness and ability of a nation and its firms to invest aggressively using complex foreign product and process technology acquired on global markets through licences, joint ventures, and other means (Porter 1990, p. 548). Competitive advantage stems mainly from favourable factor conditions as well as firm strategy, structure, and rivalry. In the innovation-driven stage, firms compete using global strategies and possess their own international marketing and service networks along with the growing reputation of their brand abroad. The full "diamond" is in place for a wide range of industries (Porter 1990, p. 552). At this stage, all the determinants of the diamond are at work and their interactions are at their strongest. Foreign manufacturing develops in those industries whose structure favours a dispersed value chain. As underlined by Porter (1990 p. 554), "the innovation-driven stage, then, marks the onset of significant foreign direct investment."

\section{Introducing MNE Activity}

Although Porter's model was generally very well accepted it also stimulated debate, in particular by international business scholars. The lack of explicit incorporation of the MNEs has led to some misunderstanding about Porter's approach. Some scholars held that the original diamond model fails to incorporate or misunderstands the effect of the activities of MNEs on the competitiveness of the host country's economy.

Some modified diamond approaches have been developed. Dunning (1993a, p. 8) argues that Porter does not sufficiently take the "globalisation of economic activity" 
into account. FDI has important effects on national competitiveness which are not adequately covered by the facet "firm strategy, structure, and rivalry." A firm engages in cross-border activities to exploit its specific ownership advantages. These advantages may initially have been based on the diamond of the home base, but their competitive assets are now largely multinationalised. Inward FDI is likely to bring new resources and technologies into a nation. Indeed, a foreign investor might import advantages from his or her home base and some of its assets could contain ownership specific advantages (Dunning 1993, p. 108). For Dunning, each facet of the diamond is linked to multinational activity, as FDI can influence factor conditions, related and supporting industries and demand conditions, as well as strategy, structure and rivalry.

Rugman's approach to the diamond is based on similar considerations. In his view, Porter's diamond model is only applicable for large countries, such as the US and it is seriously flawed when applied to small, open economies (Rugman and D'Cruz 1993). Moon et al. (1998) have, thus, extended the diamond model to a generalised double diamond model, which formally incorporates the activities of MNEs. This is not the place to resolve this discussion. The important point is that this dialogue has moved the literature forward. Both schools agree that it is firms that create wealth, and that MNEs may have an important impact on competitive development. By taking MNE activity into account, the scholars of international business have made an important contribution to the diamond model.

\section{The Impact of the Activities of MNEs on National Competitiveness}

From a historical point of view, the opinions, as well as the facts, concerning FDI have changed. In the 1970s, many host country governments and some scholars viewed inward FDI as detrimental to the host economy's welfare and development. Since the beginning of the 1990s, the view has become more optimistic suggesting that MNEs have important complementarities with local industry and may stimulate development in host economies (Markusen and Venables 1999, p. 336). Host countries hope to gain access to technologies and skills they do not yet possess (Blomström and Kokko 1998, pp. 247-248). It is argued that new ideas, technologies and working practices are diffused through dealings with domestic suppliers, demonstration, and through the movement of skilled staff (Hubert and Pain 2001, p. 136). Case studies have shown that foreign subsidiaries might introduce new know-how, stimulate competition, and transfer production techniques and management skills (Blomström and Kokko 1998, p. 256).

Policy-makers are, therefore, beginning to see MNEs as a practical and efficient method of promoting economic development, as these ownership advantages are believed not only to affect the nation's productivity directly, but also indirectly through spillovers (Narula and Marin 2003, p. 1). Indeed FDI may not only enhance competitive advantages at each stage of economic development but may even lead to a dynamic upgrading of the economy. Proponents of the investment development path argue that this process is a self-reinforcing virtuous (or vicious) cycle (see Dunning and Narula 2004, pp. 38-66). 


\section{Theoretical Framework}

Positive effects of FDI presuppose a positive gap between domestic firms and MNEs. Our analytical starting point is the widely accepted fact that MNEs possess superior technology and skills. International business theory, the OLI-paradigm in particular, argues that a firm will invest abroad only if it benefits from an ownership advantage over the domestic firms (Dunning 1993b). As stated by Dunning (1993b), firms bring with them ownership advantages that allow them to compete successfully with local firms that presumably have superior knowledge of local markets, consumer preferences and business practices. International business theory usually distinguishes two types of ownership advantage: proprietary knowledge and superior business strategy (Casson 1990, p. 86). In Schumpeterian industries the competitive assets of MNEs are likely to be related to new products and processes. In mature industries MNEs may base their competitive assets more on marketing skills or organisational advantages (Blomström and Kokko 1998, p. 250).

MNEs are increasingly seen as global networks of firms, and one of the main characteristics of these networks is the creation, diffusion and commercialisation of technological innovations (Dunning and Gugler 1994, p. 173). While the potential advantages of FDI are generally acknowledged, it is also clear "that the nature, level and extent of the benefits vary considerably" (Narula and Marin 2003, p. 1). The effective impact of FDI depends on two interdependent factors: the type of MNE activity undertaken and the absorptive capacity of domestic firms.

First, the activity of the MNE needs to be considered. On the one hand, the motivation of the MNE influences the technology gap (and, thus, the potential for spillovers). The assumption that FDI implies an ownership advantage seems reasonable if the MNE engages in market-seeking FDI (Blomström and Sjoholm 1998). This view, however, fails to take into account that FDI may also occur for resource-seeking and strategic reasons. In the case of technology-seeking (or assetaugmenting) FDI, for instance, the gap is per definition negative (see Driffield and Love 2003). On the other hand, the type of activity undertaken and the mode of entry also need to be considered. Furthermore, the internal organisation of the MNEs (i.e., multi-national strategies or global strategy: the first implies more autonomy of affiliates, whereas, the second implies a greater influence from headquarters), the value-chain activities operated abroad and other considerations play a role. All these factors determine the productivity gap between domestic firms and the MNE. In particular the benefits of resource-seeking FDI, which often results in fully owned subsidiaries with little autonomy and limited value adding activities, have been questioned by scholars (see, Driffield 2001, p. 105).

Second, there is no free learning. It is a very intuitive but, nevertheless, often neglected fact, that there need to be domestic firms with the necessary assets and technology to benefit from foreign technology in order for spillovers to occur (Dunning and Narula 2004, p. 27). MNEs are not in the economic development business and the last thing they are interested in is the diffusion of their proprietary technology or in having their business strategies copied. In other words, spillovers depend on the absorptive capacity of domestic firms. Even if local firms have the necessary ownership advantages to learn from the MNE, the national diamond must 
be at least equivalent to that of the international competition in the industry (Dunning and Narula 2004, p. 27-28). Without a minimum of technological knowhow and competence, the host region cannot become part of the international network to which MNEs provide access. Using evidence from Argentina, Narula and Marin (2003) have shown that only those firms that invested in their absorptive capacity benefited from spillovers. Absorptive capacity is linked to the technology gap. Although a larger gap between the technological capabilities of the firm and the country offers a larger potential for spillovers, foreign technology may prove useless if the gap is too large. This is a possible explanation for the fact that most studies that have found positive spillovers were conducted in developed countries (Lipsey and Sjöholm 2004, p. 8).

Various studies have suggested that FDI has an important impact on competitiveness. Barrell and Pain (1997), for instance, estimate that around 30\% of the productivity growth in the UK manufacturing between 1985 and 1995 could be associated with the effect of inward investment. Several studies have tried to link this productivity growth to direct effects and spillovers in the field of technology transfer and of the upgrading of human capital. Before moving to the empirical findings, we must, however, note that technology is a very broad concept and productivity spillovers are difficult to measure. Caution is, therefore, required when comparing different studies as both the concepts employed and the measures used vary considerably (see Görg and Strobl 2001).

\section{Technology Transfer}

FDI is generally considered a source of modern technology, in a broad sense, including product, process and distribution expertise, as well as management and marketing skills (Blomström and Kokko 1998, p. 247). Technology transfer may occur directly or through spillovers. Foreign firms may directly affect the average productivity level of the host economy by importing capital, advanced assets and proprietary technology. The MNE may directly transfer technology through licensing, supplier networks or subcontracting arrangements (Driffield 2001, p. 104). Santangelo (2005), for example, finds that such relationships seem to be positively related to the level of autonomy of the subsidiaries. However, as pointed out by Blomström and Kokko (1998), technology markets are often imperfect and transaction costs may thus be an important barrier to direct transfers. Furthermore, "as technology levels rise, the information becomes more idiosyncratic and firm-specific, and less easily transferable at arms length" (Dunning and Narula 2004, p. 27).

Inward FDI may create positive spillovers, even if MNE activity consists in wholly-owned affiliates, since many aspects of technology are a quasi-public good (Blomström and Kokko 1998, pp. 247-248). Such productivity spillovers can occur through several channels, such as demonstration effect, increased competition, and commercial ties.

Demonstration effects allow domestic firms to learn superior production technologies through arm's length relations with MNEs (Görg and Strobl 2001, p. 723). Spillovers spring from the demonstration of superior practices by foreign affiliates, resulting in what Caves (1974) terms "technical efficiency improvements." Here, the absorptive capacity of domestic firms plays a crucial role. Data from the UK 
manufacturing industry, for example, suggests that the impact is greater when domestic firms and MNEs have similar levels of productivity (Driffield and Taylor 2002).

Another productivity spillover effect is the result of a competition effect in the host country following the establishment of foreign competitors. Increased rivalry forces local firms to take action and to innovate. This may lead to an increase in productivity (Driffield 2001, p. 106). As price competition becomes more intense, domestic (and foreign) firms have an incentive to differentiate their products. Domestic consumers thus benefit from a larger variety of products at a lower price. This effect is likely to be enhanced by the fact that foreign firms are organised and managed in a different manner. In other words, FDI enlarges the pool of available management practices and approaches, while the enhanced rivalry ensures that only the fittest and most appropriate management practices survive. Some authors, however, argue that this competition effect is not a spillover effect, as there are no technology flows involved (see, for instance, Narula and Marin 2003, p. 8).

The development of related and supporting industries through consumer ties is closely linked to the competition effect. Opening the domestic market to foreign competitors will not only increase competition between the direct rivals of the MNEs, but also enhance competition at the level of local suppliers. MNEs are potentially sophisticated buyers of domestic products with stricter quality controls than domestic firms. Furthermore, MNEs can credibly threaten with vertical integration or create spin-offs to ensure supply with specialised inputs. FDI also creates forward and backward linkages, as affiliates often train and instruct their local suppliers, subcontractors and customers (Narula and Marin 2003, p. 8). So called "science-technology spillovers" may also occur through collaboration between multinationals and universities and other research institutions (Santangelo 2005, p. 6).

Econometricians searching for such effects have found evidence that inward FDI has a positive effect on domestic firms' total factor productivity and on their propensity to export (Blomstrom and Kokko 1998). Case studies have arrived at similar conclusions (see, for instance, Hobday 1995). However, several studies have found a lack of spillovers (Van Pottelsberghe and Lichtenberg 2001; Bloningen and Slaughter 2001), or even negative spillovers to domestic firms (Aitken and Harrison 1999).

\section{Upgrading of Human Capital}

The upgrading of human capital is a consequence of and a complement to technology transfer (Narula and Marin 2003, p. 6). Human capital is necessary both to enable MNEs to implement new technologies and for host countries to absorb them. The demand for skilled workers increases when firms use superior technology, as the development and effective use of technology requires human capital (Driffield and Taylor 2002; Lall 2001, pp. 128-131). Human capital is, therefore, increasingly considered a major constraint in implementing global strategies (Smale 2004, p. 2). However, a pre-existing pool of skilled labour augments the host's absorptive capacity. Several studies have shown that the lack of suitably skilled workers is an important reason for the slow adoption of new technologies (Lall 2001, p. 150).

Upgrading of human capital can occur directly and indirectly. First, MNEs can improve the quality of the local workforce through training and through learning算 Springer 
by-doing (Narula and Marin 2003, p. 1). MNEs have generally been found to.use more capital-intensive production methods than domestic firms (e.g., Bloningen and Slaughter 2001). As the level of human skills required is generally higher in capitalintensive production, we may assume that MNEs will provide more and better training for their staff. MNEs must hence train their employees and by so-doing they increase average labour productivity in the host State. However, skill needs depend on the sophistication of the activities. The level of development and the level of autonomy of the subsidiaries, thus, matters (see Lall 2001, p. 138). Second, positive productivity spillovers can occur through movement of highly skilled staff from MNEs to domestic firms (Blomström and Kokko 1998).

Several studies have found that foreign owned firms have an advantage in labour productivity over their domestic rivals and tend to pay higher wages (Narula and Marin 2003; Driffield and Taylor 2002). Using data on Ghanaian manufacturing, Görg et al. (2002) find that the wage premium is only acquired by workers who have spent time in the firm and received training, providing empirical support for the upgrading of human capital. Furthermore, although much of the superior performance of subsidiaries is attributable to more capital intensive production, substantial differences can be ascribed to the fact that foreign ownership implies a higher proportion of skilled workers (Girma et al. 2001, p. 120). Many MNEs provide in-house training and engage in collaborations with centres of higher education (UNCTAD 2005, p. 184). However, there is no comprehensive empirical evidence to prove the existence of positive spillovers on the local workforce and the conclusions of the studies done so far have been contradictory. Bloningen and Slaughter (2001, p. 373), for example, found "zero or even negative correlation" between FDI and skill upgrading, although MNE subsidiaries in the United States produce on a larger scale and are more capital intensive than domestic firms. While foreign affiliates are more active in training than their domestic counterparts, their low level of labour mobility (which is probably related to the high wages) limits spillovers. Additionally, MNEs, aim to maximise the transfer of knowledge and skills within the firm's network and to prevent external transfer (Smale 2004, p. 7). A particular problem is the degree of skilled labour required. In many situations management staff do not come from the local labour market, but are recruited within the international network (Enright 2000, p. 119). Apparently, the local share of skilled labour is usually low but increases over time (Blomström and Kokko 1998, p. 260).

Summing up, we find that despite a large theoretical consensus, empirical evidence on the effects of FDI is relatively rare and contradictory. As Görg and Strobl (2001, p. 737) point out, cross-sectional studies find greater effects of FDI than panel data, and the results also vary according to the definition of the foreign presence. We believe that previous research has two major shortcomings. First, many empirical studies have adopted an excessively narrow definition of technology, omitting nontechnological ownership advantages, such as management skills (Driffield 2001, p. 104). The activities of foreign MNEs may lead to a more efficient utilisation of inherited factors through technological advances as well the creation of sophisticated factors, in particular human capital. MNEs can indeed create factors such as specialised workforce, capital resources, advanced infrastructure and knowledge resources. However, national competitiveness depends on more than factor conditions. Focusing on factor conditions alone is, in our opinion, misleading, especially 
in the case of investment- and innovation-driven economies. The effects of FDI on the other facets of the diamond may explain why Driffield (2001), for example, finds positive effects on productivity growth, but no evidence of spillovers. Nevertheless, several studies have taken a broader approach to the effects of FDI, and have looked at non-productivity spillovers, such as "market access spillovers" and the capacity to introduce new and innovative products (e.g., Görg and Strobl 2001).

Second, agglomeration economies play an important role in the diffusion of technology (Driffield 2001, p. 104). Several studies have found that spillovers are not only positively related to the pre-existing level of productivity of the sector but that they are also largely localised (Aitken and Harrison 1999; Driffield and Love 2003). There are two likely reasons for this phenomenon. First, MNEs tend to focus the innovative activities of their international networks in regional centres of excellence (Aitken and Harrison 1999; Cantwell and Iammarino 2000). Second, clustering fosters the rapid diffusion of know-how and skills as the strong linkages and externalities enhance absorptive capacity. Several studies have identified the importance of proximity in industries where success depends on new economic knowledge (e.g., Audretsch and Feldman 1996). In our opinion, the previous empirical and theoretical literature has not sufficiently considered the second argument. The cluster dimension needs to be taken into account, and, in particular, the link between clusters and absorptive capacity needs to be further developed.

\section{The Impact of the Activities of MNEs on National Competitiveness: The Cluster Dimension}

The prosperity of a location depends on the productivity of the firms located there, what they choose to do, and how they compete. Firms can be productive in any industry if they employ sophisticated methods, use advanced technology, and supply unique products or services (Porter 1998, p. 209). The sophistication and productivity with which firms compete in a location is strongly influenced by the quality of the business environment. According to Porter's theory, the more decisive aspects of the business environment are often cluster-specific (Porter 1998, p. 210).

Technology transfer and the upgrading of human capital have proven to be highly local phenomena (see above). Consequently, in order to assess the effects of MNEs on national competitiveness, we must move beyond the theoretical framework on spillovers outlined above. Our hypothesis is that proximity and networking enhance the absorptive capacity of domestic firms and thus the positive effects of FDI. Several dimensions identified in the theory of international business as well as in the theory of clusters provide support for this view.

\section{FDI and Clusters}

Clusters and foreign investments are interdependent phenomena. On the one hand, clusters may attract FDI by providing access to resources, technologies and markets (Porter 1998, p. 241). On the other hand, MNEs induce externalities in clusters by providing access to assets, skills, and technologies, to the domestic components of the cluster (Birkinshaw and Sölvell 2000, p. 8). In this paper, we focus on one of

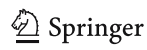


these interactions: the effects of MNEs on clusters in their host country. As noted by Enright (2000, p. 118), "If there has been relatively little research on the contribution that clusters make to MNEs, there has been even less on the contribution that MNEs make to clusters."

While the literature on clusters originally centred on domestic firms, the process of globalisation has meant that clusters increasingly have significant levels of foreign ownership (Birkinshaw 2000, p. 93). Some industry clusters, such as software and biotechnology clusters in Ireland or the equipment and software cluster in Singapore (UNCTAD 2005, p. 205), have upgraded largely through FDI. Others, such as the automobile cluster in Detroit or the cinematographic cluster in Hollywood, were domestically owned for many decades but are now facing increasing levels of foreign ownership (Birkinshaw 2000, p. 93).

Two important effects of MNEs on host country clusters may be distinguished. First, MNEs may help the emergence of new clusters and second, MNEs may help the development of existing ones. As noted by Porter, "cluster development can be seeded and reinforced by inbound FDI" (Porter 1998, p. 247). Empirical studies, however, have shown that the impact of MNEs on the creation of clusters is not evident. While clusters can generate significant productivity spillovers from FDI, this occurs mainly in pre-existing clusters. We will focus on the effects of FDI on the evolution of existing clusters while not excluding the role of foreign MNEs in the creation of clusters. Indeed, in some cases, MNEs have played a major role in such creations. For example, in Singapore, R\&D by MNEs was a key factor in creating an innovation and industrial cluster around biomedical sciences, such as pharmaceuticals and biotechnology (UNCTAD 2005, p. 189).

In our opinion, clustering enhances the absorptive capacity of the host State. As stated previously by Marshall (1920), geographical proximity enhances the diffusion of knowledge and technical progress. A key advantage of clusters is that they offer a pool of specialised employees (Porter 1998, p. 216). The specialisation of the workforce implies that many of the skills built up by an MNE and transferred through labour mobility can be used by other firms working in similar or related fields. Furthermore, the entry of a MNE may attract talented people to the cluster and, thereby, endorse the cluster's competitive advantage. Another advantage of clusters is the rapid access to and diffusion of information, e.g., about technology and markets (Porter 1998, p. 216). Much information is tacit and its diffusion may be fostered through the ongoing relationships between the cluster participants. For example, MNEs are likely to influence institutions and build public goods, such as specialised infrastructure, which are important determinants for a cluster's success (Porter 1998, p. 218). Finally, firms within a cluster can be more innovative because they can rapidly perceive and seize new opportunities on account of the flexibility and capacity of local suppliers (Porter 1998, p. 221). The ownership advantage of MNEs, for example proprietary technology, may be an important link in the value chain, and excluding FDI may obstruct innovation within the cluster.

As noted by Enright (2000, p. 130), benefits from MNE activities in clusters are, therefore, likely to "go well beyond the direct benefits of employment, output, and skill transfer, as well as the indirect benefits of spillovers." It is, hence, indispensable to include the theory of clusters, in particular by considering the types of activity of the cluster (local-oriented or traded clusters), its mode of organization, the role of 
the private as well as the public components, the activities and performances of the research and education institutions, the dynamism of linkages within the cluster, together with the nature of the Location-advantages (L-advantages) offered by the cluster to the MNEs.

All the above-mentioned features will influence the type and the strength of the spillover effects of the MNE on the cluster. There are, however, no comprehensive approaches that include all these aspect in a global framework. The major contributions on this issue relate to specific aspects of the effects of FDI on clusters according to specific categorization of clusters. The main findings, which can nevertheless help us to develop a conceptual framework, are discussed below.

\section{Effects of FDI According to the Features of the Cluster}

As stated by Enright (2000, p. 134), we must comprehend the nature of each cluster in order to take full advantage of potential spillovers. Birkinshaw (2000, pp. 99-103) analyses the role of foreign ownership on cluster upgrading according the life-cycle stage of industry and to the cluster dynamism.

Birkinshaw distinguishes two stages in the life-cycle of industry: high-growth industries (e.g., electronics, information technology, telecommunications) and mature industries defined as industries whose rate of top-line growth is no more than the rate of productivity growth on a worldwide basis (e.g., automobiles, chemicals, electrical equipment). The level of dynamism of the industry cluster in turn reflects "the scope of activities and quality of the interlinkages among activities in the cluster" (Birkinshaw 2000, p. 101). The analysis shows that the effect of MNEs on clusters is greater in growing industries than in mature ones and in dynamic clusters than in dormant ones. While this model helps in analysing the effects of MNEs in specific cases according to the degree of dynamism of the cluster and the stage of development of the industry, it is too general to provide a clear framework regarding the effects of foreign ownership on clusters.

Birkinshaw's results are supported by Rugman and Verbeke (2002). They arrive at the same conclusion about the spillovers on dynamic clusters which usually benefit from the presence of inward FDI, whereas the results are more uncertain in the case of weak or immature clusters, in which foreign firms typically limit the scope and depth of their cluster ties (Rugman and Verbeke 2002).

Rugman and Verbeke (2002) make a distinction between four types of clusters. First, they distinguish symmetrical clusters from asymmetrical ones. Asymmetrical clusters are built around one, or a few, core companies (i.e., firms that drive the cluster); whereas symmetrical clusters consist of several, more equal partners, with no particular firm playing a dominant role. Second, they distinguish between domestic clusters and "transborder" clusters characterized by an important foreign component, typically through the presence of MNEs. This study provides some useful insights on the effects of FDI on clusters within which one MNE or a few MNEs play(s) a significant role.

Holm et al. (2002) studied the impact of MNEs on local clusters by analysing the case of foreign owned subsidiaries in Sweden. They found that a dynamic business environment leads to important subsidiary competencies that, in turn, lead to positive external effects on the surrounding cluster (Holm et al. 2002, p. 27). 
For his analysis of the role of FDI in economic development, Ozawa (1992) developed a "dynamic paradigm of FDI facilitated development." Since the industrial revolution, he argues that industrialisation has essentially been based on copying (Ozawa 1992, p. 33). In Ozawa's model, FDI patterns change with the structural transformation of the economy (Ozawa 1992, p. 35). Through the development of new technologies, FDI pushes nations to develop new comparative advantages and eventually to move to the next stage of economic development. He gives the example of the Asian tigers that have progressed from the factor-driven stage to the investment-driven stage. The author concludes that more conceptual work is needed to investigate the effects of FDI on innovation-driven economies (Ozawa 1992, p. 50). A similar approach is taken by Dunning and Narula (2004) in their "investment development path." The authors also argue that different types of FDI are attracted to economies at different stages of economic development. They go on to propose a model of economic development based on FDI. Although these approaches do not take the cluster dimension into account, they offer interesting avenues for further research on the interactions between FDI and clusters. The stage of economic development of the cluster may be an important variable, as clusters at the factor-driven stage are likely to differ significantly from innovation-driven clusters.

These contributions are helpful in analysing inward FDI according to some types of clusters in some countries. However, we still lack a comprehensive conceptual framework for identifying and assessing the multi-faceted role of MNEs in the competitiveness of their host country clusters. A further step would be to consider the main criteria identified by the international business community in order to understand the reasons, the functioning, and the effects of MNEs, as well as the main features of clusters and to combine these in a "holistic approach."

\section{Towards a General Conceptual Approach}

The cluster approach certainly offers a pertinent and realistic approach to assessing the externalities created by inward FDI. This approach offers firms as well as governments powerful insights on how to enhance competitiveness by maximizing the positive externalities of established foreign MNEs and by attracting specific foreign firms to a particular cluster. It not only helps government to implement the right policies in order to create a win-win situation benefiting both the MNE's interests and regional development, but also provides firms with the right template for developing and implementing their strategies. As stated above, the pool of specialised and experienced employees as well as the rapid diffusion of knowledge in a cluster magnifies the benefits of FDI.

The complexity of the phenomena calls for a general conceptual framework, encompassing the elements discussed above: the national diamond of competitiveness, the type of cluster, the attractiveness of the location, its absorptive capacity, and multinational activity. In Fig. 1, we develop our framework. The links between the elements are of particular importance.

(1) Clusters constitute one "facet" of the diamond (related and supporting industries), but they are to be considered as a manifestation of the interactions between all four facets (Porter 1998, p. 213). Empirical evidence suggests that 


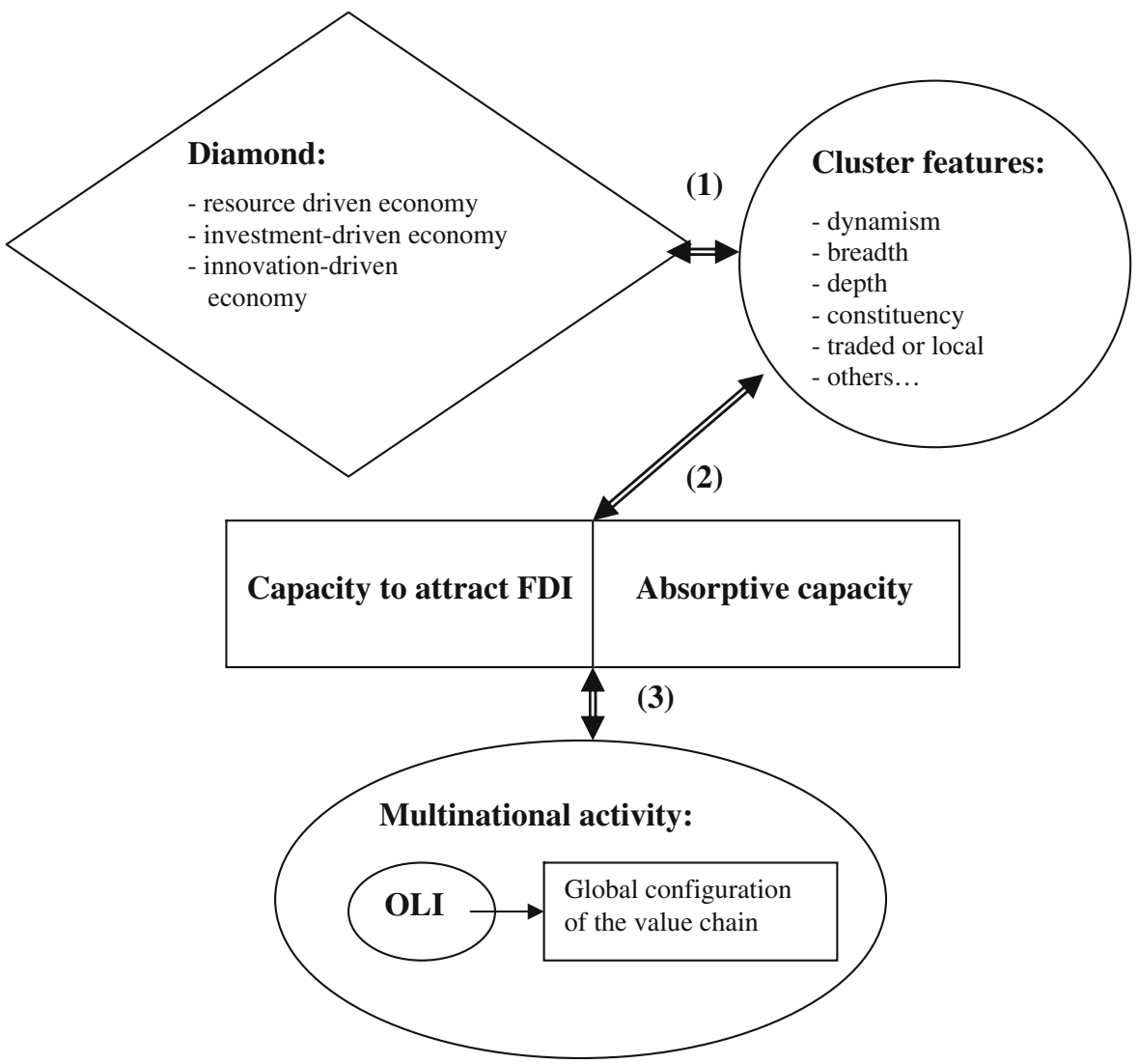

Fig. 1 A general conceptual framework

clusters which base their competitiveness primarily on factor conditions are less competitive than clusters that base their competitiveness on all the facets of the diamond (Van der Linde 2003, p. 144). Although empirical research on clusters is still in its infancy (see Van der Linde 2003, p. 148), these findings align well with the model of competitive development, which states that the relevance of the different facets of the diamond of national competitiveness depends on the stage of economic development. The existence and success of a cluster, thus, depends on the different facets of the diamond and the stage of economic development. At the same time, the features of the cluster feed back into the diamond. The fact that a wide range of phenomena is grouped under the term "cluster" calls for a differentiation of cluster dimensions, e.g., into geographical scope, density, breath, and depth (Enright 2000, pp. 316-317).

(2) The depth of the cluster, the sophistication of the activities undertaken, the dynamism of the industries involved, its constituents, and other features determine both the location's ability to attract FDI and its absorptive capacity. The more dynamic a cluster, the better developed its linkages, and the larger its share of world markets, the higher both the magnetism of the cluster and its ability to absorb spillovers. Indeed, by upgrading the capabilities of its 
constituency, a cluster may increase the positive spillover effects of a MNE, and could also reduce some of the negative effects of MNEs. The impact of the activities of MNEs on host countries, based on a cluster approach, has to be seen as a dynamic process. In fact, MNEs may have significant effects not only on the specific cluster within which they are competing but may also have indirect effects on other clusters due to a spreading effect across clusters. Again, this link is reciprocal, as a strong ability to attract and a high absorptive capacity leads to an upgrading of the cluster features.

(3) Multinational activity is linked to the location advantages and to the absorptive capacity. According to the OLI paradigm, a firm will become a multinational if it has an ownership advantage it wants to develop or exploit, if the host State has a location advantage, and if it is more profitable to internalise the operation (integration advantage). These three factors determine the type of activity, i.e., which elements of the value chain will be located abroad, as well as the mode of entry (e.g., fully owned subsidiary, joint venture, strategic alliance, greenfield investment, or acquisition, etc.). The actual benefits of FDI will depend not only on the type of FDI attracted but also on the absorptive capacity of the economy. Absorptive capacity and competitive development are highly interdependent as more complex technologies have greater potential for future learning (Lall 2001, p. 135). As shown for example by Narula and Marin (2003), where spillovers have occurred, this was where domestic firms had demonstrated high levels of investment in absorptive capacities. The link between multinational activity and the local determinants (host attractiveness and absorptive capacity) is arguably the most complex. Not only will the MNE influence the decisions of other MNEs to enter the location, but it will also influence the absorptive capacity of the host State, for instance, through labour spillovers.

All these elements contribute to the concrete impact of FDI. Consequently, domestic firms can benefit from inward FDI, but a proactive policy on the part of domestic firms and government is required to actually derive benefits from foreign MNEs (Narula and Marin 2003).

\section{Conclusion and Policy Implications}

Combining Porter's cluster approach with the theory of international business has provided important insights. MNEs potentially have a beneficial impact on the host country, as they are a source of technology in a broad sense and can lead to an upgrading of human capital. The effective impact of FDI, however, depends on the type of activity undertaken and the absorptive capacity of the host State. There are good reasons to believe that these factors are both influenced by the existence and type of clusters in the region. The conceptual framework we have developed connects these elements and highlights their interconnections.

These findings have implications for policy-makers aiming to attract FDI and achieve maximum benefits. Governments play a crucial role in shaping the com- 
petitiveness of their nations (Porter 1990). Policies, such as investment protection and liberalisation, are necessary but not sufficient. A number of European governments have assumed a cluster approach to their economic policy, including The Netherlands, Denmark, and the United Kingdom (Ketels 2004, p. 3). Cluster policy and policies towards attracting FDI should indeed be considered together, as spillovers and agglomeration economies in general do not occur spontaneously, but require investment in education infrastructure (Young et al. 1994). Policy-makers ought to consider whether the FDI attracted actually "fits" their economy (Oxelheim and Ghauri 2004, p. 9) by asking: What kind of investment is attracted and how can our economy enhance its competitiveness through technology transfer and the upgrading of human skills? FDI-related policy should aim at attracting activities with high added value and provide incentives to firms to locate more elements of their value chain in the country.

At the same time, policy-makers should take the absorptive capacity of their region into account. Given that clusters are a powerful tool for upgrading the efficiency of their constituents, we argue that the existence of a cluster may allow domestic firms to benefit more from spillovers from MNEs and, thus, to get better results in terms of increased productivity. The strong linkages and externalities in a cluster foster the rapid diffusion of know-how and skills; clustering, hence, enhances absorptive capacity. The existence and depth of the host cluster is a variable that must be considered when assessing the impact of the investment. In other words, FDI-related policies must become more selective and more targeted. Instead of focusing on short-term objectives, such as the number of jobs created, or the total value of the investment attracted, policy should consist in exploiting and creating synergies between the ownership advantages of the MNE and the competitive advantage of the location. FDI policies, therefore, need to be embedded in a broader policy of cluster development (see Porter 2000). Policy-makers need to achieve "strategic fit" between their objectives (e.g., enhancing competitive advantages, creating employment) and their means (types of investment incentives) in order to maximise the benefits of FDI. Finally, it is important to keep in mind that "foreign investment alone is insufficient" (Porter 1998, p. 252). For a cluster to succeed, the government must influence the business environment throughout the diamond (Porter 1998, p. 251). In this respect, the tendency to race for FDI by allowing international mergers or acquisitions that do not comply with the law on competition is very problematic (see Gugler 2004).

The theoretical framework outlined above implies that there is no one-size-fits-all policy. Different policies are necessary under different circumstances. This paper has tried to develop certain guidelines for cluster practitioners, which need to be adapted to the particular case. We find that, ceteris paribus, clustering is likely to increase the beneficial effects of FDI as the absorptive capacity of firms in a cluster is greater than that of dispersed firms. However, aspects, such as the activities performed by the MNE, the state of economic development, the type of cluster, negative economies of agglomeration, and many other considerations determine the concrete impact of FDI on the host economy.

Further research is needed to create a more formal model. Furthermore, several extensions of our framework are imaginable. In particular, we need to know which effects of FDI are likely to occur in all clusters and which will differ according to the 
situations outlined above. Finally, the situation calls for further empirical studies which take the findings of this paper into account.

\section{References}

Aitken, B., \& Harrison, A. (1999). Do domestic firms benefit from direct foreign investment? Evidence from Venezuela. American Economic Review, 89(3), 605-618.

Audretsch, D., \& Feldman, M. (1996). R\&D spillovers and the geography of innovation and production. American Economic Review, 86(3), 630-640.

Barrell, R., \& Pain, N. (1997). Foreign direct investment, technological change, and economic growth within Europe. Economic Journal, 107, 1770-1786.

Birkinshaw, J. (2000). Upgrading of industry clusters and foreign investment. International Studies of Management \& Organization, 30(2), 93-113.

Birkinshaw, J., \& Sölvell, Ö. (2000). Preface. International Studies of Management \& Organization, 30 (2), 3-9.

Blomström, M., \& Kokko, A. (1998). Multinational corporations and spillovers. Journal of Economic Surveys, 12(2), 247-277.

Blomström, M., \& Sjoholm, F. (1998). Technology transfer and spillovers: Does local participation with multinationals matter? NBER Working Paper 6816, MA: Cambridge.

Bloningen, B. A., \& Slaughter, M. J. (2001). Foreign-affiliate activity and U.S. skill upgrading. Review of Economics and Statistics, 83(2), 362-379.

Cantwell, J., \& Iammarino, S. (2000). Multinational corporations and the location of technological innovation in the UK regions. Regional Studies, 34(4), 317-332.

Casson, M. (1990). Enterprise and competitiveness. A systems view of international business. Oxford: Clarendon.

Caves, R. E. (1974). Multinational firms, competition, and productivity in host country markets. Economica, 41, 176-193.

Driffield, N. (2001). The impact on domestic productivity of inward investment in the UK. Manchester School, 69(1), 103-119.

Driffield, N., \& Love, J. H. (2003). Foreign direct investment, technology sourcing and reverse spillovers. Manchester School, 71/6, 659-672.

Driffield, N., \& Taylor, K. (2002). Spillovers from FDI and skill structures of host-country firms. Discussion Papers in Economics 02/4, Department of Economics, University of Leicester.

Dunning, J. H. (1993). The globalisation of business. London: Routledge.

Dunning, J. H. (1993a). Internationalizing Porter's diamond. Management International Review, 33, 7-15 (special issue).

Dunning, J. H. (1993b). Multinational enterprises and the Global economy. Addison Wesley.

Dunning, J. H., \& Gugler, P. (1994). Technology based cross-border alliances. In D. J. Jeremy (Ed.), Technology transfer and business enterprised. Cheltenham, UK: Edward Elgar.

Dunning, J. H., \& Narula, R. (2004). Multinationals and industrial competitiveness. A new agenda. Cheltenham, UK: Edward Elgar.

Enright, M. J. (2000) The globalisation of competition and the location of competitive advantage: Policies towards regional clustering. In N. Hood, \& S. Young (Eds.), The globalisation of multinational enterprise activity and economic development (pp. 303-331). London: MacMillan.

Girma, S., Greenaway, D., \& Wakelin, K. (2001). Who benefits from foreign direct investment in the UK? Scottish Journal of Political Economy, 48(2) 119-133.

Görg, H., \& Strobl, E. (2001). Multinational companies and productivity spillovers: a meta-analysis. Economic Journal, 111, F723-F739.

Görg, H., Strobl, E., \& Walsh, F. (2002). Why do foreign owned firms pay more? The role of on-the-job training. Discussion Paper no. 590, Institute for the Study of Labour (IZA), Germany.

Gugler, P. (2004). The WTO and the race for inward FDI in the European union. In L. Oxelheim, \& P. Ghauri (Eds.), European Union and the race for foreign direct investment in Europe (pp. 59-100). Oxford: Elsevier.

Hobday, M. (1995). Innovation in East Asia: The challenge to Japan. London: Edward Elgar.

Holm, U., Malmberg, A., \& Sölvell, Ö. (2002). MNC impact on local clusters - the case of foreign owned subsidiaries in Sweden. Paper presented at the EIBA Conference. 
Hubert, F., \& Pain, N. (2001). Inward investment and technical progress in the United Kingdom manufacturing sector. Scottish Journal of Political Economy, 48(2), 134-147.

Ketels, C. (2004). European clusters. Published in structural change in Europe 3-innovative city and business regions. Bollschweil: Hagbarth.

Lall, S. (2001). Competitiveness, technology and skills. Cheltenham: Edward Elgar.

Lipsey, R., \& Sjöholm, F. (2004). Host country impacts of FDI: Why such different answers? Working Paper 192.

Markusen, J. M., \& Venables, A. J. (1999). Foreign direct investment as a catalyst for industrial development. European Economic Review, 43, 335-356.

Marshall, A. (1920/1960). Principles of economics, book IV: The agents of production, land, labour, capital and organization (9th ed.). London: Macmillan.

Moon, H.-C., Rugman, A., \& Verbeke, A. (1998). A generalized double diamond approach to the international competitiveness of Korea and Singapore. International Business Review, 7, 135-150.

Narula, R., \& Marin, A. (2003). Foreign direct investment spillovers, absorptive capacities and human economic development: Evidence from Argentina. ILO Working Paper no. 96.

Oxelheim, L., \& Ghauri, P. (2004). The race for FDI in the European Union. In L. Oxelheim, \& P. Ghauri (Eds.), European Union and the race for foreign direct investment in Europe (pp. 59-100). Oxford: Elsevier.

Ozawa, T. (1992) Foreign direct investment and economic development. Transnational Corporations, 1/1, 27-54.

Porter, M. E. (1990). The competitive advantage of nations. Boston MA: Macmillan.

Porter, M. E. (1998). On competition. Boston MA: Harvard Business School.

Porter, M. E. (2000). Location, competition, and economic development: Local clusters in a global economy. Economic Development Quarterly, 14(1), 15-34.

Rugman, A., \& D’Cruz, J. (1993). The "Double Diamond" model of international competitiveness: The Canadian experience. Management International Review, 33, 17-39 (special issue).

Rugman, A., \& Verbeke, A. (2002). Multinational enterprises and clusters: An organising framework. Working Paper.

Santangelo, G. D. (2005). FDI and localised spillovers in peripheral areas: The role of location motives and market relationships in Etna Valley. Paper presented at the EIBA Conference.

Smale, A. (2004). HRM integration in the global firm: A knowledge transfer perspective. Paper presented at the EIBA Conference.

UNCTAD. (2005). World investment report. Transnational corporations and the internationalisation of $R \& D$. New York and Geneva: UNCTAD.

Van der Linde, C. (2003). The demography of clusters-findings from the cluster meta-study. In J. Bröcker, D. Dohse, \& R. Soltwedel (Eds.), Innovation, clusters and interregional competition (pp 130-149). Berlin, Heidelberg, New York: Springer.

Van Pottelsberghe de la Potterie, B., \& Lichtenberg, F. (2001). Does foreign direct investment transfer technology across borders. Review of Economics and Statistics, 83(3), 490-497.

Young, S., Hood, N., \& Peters, E. (1994). Multinational enterprises and regional economic development. Regional Studies, 28(7), 657-677. 